УДК 37(091)(477):378.147:811

DOI:

Лілія Овчаренко, аспірант кафедри загальної педагогіки та дошкільної освіти Дрогобицького державного педагогічного університету імені Івана Франка

\title{
ТЕНДЕНЦІЇ Й ОСОБЛИВОСТІ ВИВЧЕННЯ ІНОЗЕМНИХ МОВ МАЙБУТНІМИ ВЧИТЕЛЯМИ НЕФІЛОЛОГІЧНИХ СПЕЦАЛЬНОСТЕЙ У 70-Х - 80-Х РОКАХ ХХ СТОЛІтТя
}

У статті здійснено аналіз процесу трансформаиії ідеологічних засад, організаційних умов $і$ методики навчання іноземної мови майбутніх учителів нефілологічних спеціальностей у 70-x-80-х рр. ХХ ст. 3'ясовано, щзо в зазначений період змінилися пріоритети щзодо вивчення іноземних мов у педагогічних закладах вищої освіти: вони хоча й набули професійно орієнтованого характеру, однак і надалі здебільшого зводилися до читання і перекладу іноземної літератури з фаху.

Ключові слова: педагогічні інститути; вчителі нефілологічних спеціальностей; іноземні мови; форми організачї; принципи і методи навчання.

Jim. 15.

Liliya Ovcharenko, Postgraduate Student of the General Pedagogy and Preschool Education Department Drohobych Ivan Franko State Pedagogical University

\section{TENDENCIES AND PECULIARITIES OF STUDY OF FOREIGN LANGUAGES BY FUTURE TEACHERS OF NON-PHIL OLOGICAL SPECIALTIES IN THE 70'S - 80'S OF THE TWENTIETH CENTURY}

The article analyzes the process of transformation of ideological foundations, organizational conditions and methods of teaching foreign languages for future teachers of non-philological specialties in the 1970's and 80's. It was clarified that during this period the priorities for studying foreign languages in higher educational institutions changed: they, although they acquired a professionally oriented character, however, for the most part, were later reduced to reading and translating foreign literature in the specialty. The training of students remained rather low; optional classes and foreign language courses were not effective enough; there was insufficient methodological training of foreign language teachers and a lack of specialized literature.

1980s were marked by a large-scale reform of the system of public education. There were new forms of studying general subjects - classes with in-depth study of individual subjects, including foreign languages. During this period, future teachers showed more interest in the discipline, in particular the problem of independent work on expanding their professional knowledge by means of a foreign language. Such interest was explained by the fact that in the conditions of increased amount of professional knowledge necessary for future specialists, it was important to help them navigate in the flow of information related to the chosen pedagogical specialty. In this regard, greater attention was paid to the selection of highly informative professional texts and the development of multilevel training exercises.

In the late 80's of the twentieth century the teachers of science expressed the actual proposals on the selection and structuring of the contents of the teaching material, introduction of new principles and methods of teaching foreign languages, improving the forms and means of organizing the educational process, but due to a number of negative reasons (lack of scientific and pedagogical staff of the relevant qualification; strict unification curricula; reduction of the number of hours to study a foreign language to 120; excessive overload of students through the intensification of the educational process; low level of preparedness of prospective students, etc.), many innovations were not embodied in the practice of foreign language training of future teachers of non-philological specialties.

Keywords: pedagogical institutes; a teacher of non-philological specialties; foreign languages; forms of organization; principles and methods of teaching.

П остановка проблеми. За умов євроінтеграції України зростають вимоги щодо іншомовної компетенції працівників різного рівня. Це зумовлює виникнення все нових, більш інтенсивних методів навчання іноземних мов, інноваційних форм організації освітнього процесу. Для того, щоб форми і методи були більш ефективними та відповідали сучасним вимогам і реаліям важливо дослідити попередній досвід навчання іноземних мов у педагогічних закладах вищої освіти.

Аналіз основних досліджень та публікацій. Дослідженням проблеми теорії і практики навчання іноземних мов у немовних вишах займалося чимало вітчизняних учених О. Бирюк, М. Вахницька, О. Вовк, Т. Глушко, 


\section{ТЕНДЕНЦЇЙОСОБЛИВОСТІ ВИВЧЕННЯІНОЗЕМНИХ МОВМАЙБУТНІМИ ВЧИТЕЛЯМИ НЕФІЛОЛОГІЧНИХ СПЕЦІАЛЬНОСТЕЙ У 70-Х-80-Х РОКАХ ХХ СТОЛІТТЯ}

Р. Гришкова, О. Кміть, О. Кузнєцова, Л. Лазоренко, I. Левчик, С. Мелікова, Н. Микитенко, Н. Мукан, Н. Петранговська, Л. Шерстюк й ін. Ретроспективний аналіз системи підготовки майбутніх учителів іноземних мов у педагогічних закладах вищої освіти у другій половині XX - на початку XXI ст. здійснили В. Безлюдна та О. Околович. Однак процес навчання іноземних мов майбугніх учителів нефілологічних спеціальностей у 70 - 80 -х роках XX ст. не став предметом окремої наукової розвідки.

Мета статті полягає в аналізі основних процесів трансформації змісту та методики навчання іноземних мов майбутніх учителів нефілологічних спеціальностей у 70-х - 80-х р. ХХ ст.

Виклад основного матеріалу дослідження. Статус іноземних мов, організація і методика їх вивчення у педагогічних закладах вищої освіти впродовж 70-х рр. загалом не змінилися порівняно з 60-ми pp. ХХ ст., коли була ухвалена важлива Постанова уряду СРСР “Про поліпшення вивчення іноземних мов” [10]. Аналіз архівних даних свідчить, що у 70-х pp. ХХ ст. в загальноосвітніх школах працювало чимало вчителів іноземних мов без спеціальної педагогічної освіти; не вдалося досягнути паритетного розподілу іноземних мов, тому у школах переважали німецька й англійська мови; якість підготовки учнів залишалася доволі низькою; факультативні заняття і курси іноземних мов виявилася недостатньо ефективними; відчувалася недостатня методична підготовка вчителів іноземних мов і дефіцит спеціальної літератури тощо [4].

Однак у 70-х рр. ХХ ст. певні позитивні тенденції у вивченні іноземних мов все ж спостерігалися, адже були зумовлені переорієнтацією вищої освіти з технічних напрямів підготовки на гуманітарні. У зв'язку зі збільшенням чисельності школярів, які вивчають іноземні мови, та прийнятим урядом напрямом на гуманітаризацію системи освіти відбувається створення нових факультетів іноземних мов у педагогічних інститутах Івано-Франківська, Луцька, Дрогобича та ін. Загалом у 1972 1973 н.р. в Україні підготовку вчителів іноземних мов здійснювали 14 педагогічних інститутів [5].

80-ті pp. XX ст. були позначені масштабною реформою системи народної освіти як рушійної сили, що забезпечує прогрес і процвітання СРСР, та прагненням громадськості до демократизації і гуманізації суспільства. Уперше було порушено питання щодо неперервної освіти та їі випереджувального характеру відносно темпів розвитку науково-технічного прогресу. 3'являються нові форми навчання загальноосвітніх предметів
- класи 3 поглибленим вивченням окремих предметів, у т.ч. іноземних мов, набуває поширення іншомовне навчання дітей дошкільного та молодшого шкільного віку.

У вищій педагогічній школі посилилася тенденція до фундаменталізації загальноосвітніх і професійних знань, широкопрофільності та практичної спрямованості підготовки майбутніх учителів. Ця тенденція зумовила перегляд чинних навчальних планів з урахуванням кваліфікаційних характеристик педагогічних працівників. 31981 1982 н.р., відповідно до рішення колегії Міністерства вищої і середньої спеціальної освіти СРСР за № 14/1 від 8 квітня 1981 р., у педагогічних інститутах розпочалася робота над розробкою нових навчальних планів, які б враховували рекомендації щодо необхідного рівня знань, умінь і навичок майбутніх учителів, розміщені у №12 міністерського бюлетеня [9].

На XXVII з'їзді КПРС було поставлено завдання перебудови вищої і середньої спеціальної освіти. 1 червня 1986 р. був надрукований проект Постанови ЦК КПРС і Ради Міністрів СРСР “Основні напрями перебудови вищої і середньої спеціальної освіти в країні”, обговорення якого тривало дев'ять місяців, де вказувалося, що “фахівець сьогоднішнього дня повинен володіти грунтовною марксистсько-ленінською підготовкою, сучасним економічним мисленням, навичками управлінської, організаторської та виховної роботи, активними методами використання електроннообчислювальної техніки стосовно до профілю своєї діяльності, високою загальною культурою, знанням іноземної мови" $[12,3]$.

У пресі розгорнулася гостра дискусія щодо напрямів, шляхів і засобів реформування, педагогічною громадськістю були висунуті вимоги проведення більш рішучих заходів щодо пришвидшення реформаторських кроків, розвитку демократичних принципів управління вищою школою, скасування адміністративнобюрократичного керівництва народною освітою. В Україні зазначені проблеми доповнювалися національними. Передовсім, це стосувалося “витиснення” української мови 3 освітнього процесу в закладах вищої освіти, що болісно сприймалося свідомою i патріотично налаштованою інтелігенцією. Так, наприклад, в середині 80-х pp. ХХ ст. в Киӥвському педагогічному інституті імені О.М. Горького менше третини природничих і половини соціальногуманітарних дисциплін викладалося українською мовою, в “фондах київських бібліотек література українською мовою становила лише чверть від усіх примірників" $[13,313]$. Також була відчутною 


\section{ТЕНДЕНЦІї Й ОСОБЛИВОСТІ ВИВЧЕННЯІНОЗЕМНИХ МОВ МАЙБУТНІМИ ВЧИТЕЛЯМИ НЕФІЛОЛОГІЧНИХ СПЕЦІАЛЬНОСТЕЙ У 70-Х-80-Х РОКАХ ХХ СТОЛІТТЯ}

незбалансованість за напрямами підготовки фахівців і територіальним розміщенням вишів: найбільша кількість закладів вищої освіти належала до педагогічного та інженернотехнологічного напрямів, а найвища їх концентрація спостерігалася у промислових центрах - Києві, Харківській, Одеській, Львівській, Дніпропетровській, Донецькій областях, де навчалося 63,1 \% всіх студентів [6].

Ключовими фігурами в успішному проведенні освітніх реформ мала стати нова генерація вчителів широкого профілю. Основні надії уперіод перебудови вищої педагогічноїшколи кінця 80-х рр. XX ст. українська академічна громадськість пов' язувала саме 3 демократизацією, вузівською автономією, децентралізацією, академічними свободами тощо. Були укладені нові навчальні плани для педагогічних закладів вищої освіти, які передбачали поглиблення як суспільно-політичної, так і психолого-педагогічної та спеціальної підготовки, зміцнення зв' язків теорії зі шкільною практикою. Тут були досягнуті певні успіхи, однак це не вирішило основного завдання реформування вищої педагогічної освіти - підвищення якості фахової підготовки майбутніх учителів. Крім цього, часткова автономія вишів призводила й до негативних тенденцій, які торкалися передовсім загальноосвітніх дисциплін. Так, наприклад, в п’ятирічному навчальному плані 1987 року, призначеного для підготовки вчителів за спеціальністю "Музика 3 додатковою спеціалізацією - педагогіка" кількість годин на вивчення іноземної мови була скорочена вдвічі, до 120 годин.

У 1987 - 1988 н.р. в Московському державному інституті іноземних мов імені М. Тореза офіційно була створена кафедра методики викладання іноземної мови в немовному виші, яка здійснювала спеціальну підготовку науковопедагогічних кадрів для вищої школи $[11,123]$.

3-поміж вимог, які висувалися на той час ученими-методистами, була необхідність формування у студентів лінгвокраїнознавчих знань й умінь. Ними пропонувалося запровадити лінгвокраїнознавчий підхід, при якому“сама мова виступає джерелом відомостей про історію та культуру країни, мова якої вивчається" [3, 15]. Майже одностайно підтримувалася думка про доцільність проходження педагогами стажувань у країнах, мова якої ними вивчалася.

Потреба в розробці нових навчальних програм стала причиною виникнення нових ідей і теорій, які знайшли своє відображення в практиці навчання іноземної мови. Тут передовсім слід згадати комунікативний метод, розроблений
Є. Пасовим, і пов'язану з ним ідею формування мотивації студентів до вивчення іноземної мови, а також шляхи розв'язання проблеми статусу методики як самостійної науки нового типу. Методика викладання іноземної мови у немовних вишах одразу ж набула солідної теоретичної бази, а сама іншомовна освіта все більш ставала професійно орієнтованою: "Не можна залишати поза увагою функцію іноземної мови як засобу формування професійної спрямованості (що має першорядне значення), тобто інтересу до своєї майбутньої професії та прагнення отримати знання з більшої кількості комунікаційних каналів, одним 3 яких стає володіння іноземною мовою, що забезпечує можливість ознайомлення студентів із досягненнями в професійній сфері за кордоном" $[14,5]$. Викладачі більше уваги почали приділяти розвитку в студентів навичок вербального спілкування, взаємозв' язку навчання всіх видів мовленнєвої діяльності й урахування специфіки кожної 3 них.

Величезний внесок у розробку теорії професійно орієнтованого навчання зробив М. Ляховицький, обгрунтувавши принцип професійної спрямованості навчального матеріалу 3 іноземної мови для вивчення студентами немовних вишів [8]. Автор підкреслював, що вивчення іноземної мови має бути не самоціллю, а засобом досягнення мети підвищення рівня освіченості, ерудиції в межах будь-якої спеціальності. Врахування специфіки профільних спеціальностей, на думку автора, повинно проводитися за такими напрямами: робота над спеціальними текстами; вивчення спеціальних тем для розвитку усного мовлення; вивчення словника-мінімуму за відповідною спеціальністю; створення викладачами посібників для активізації граматичного та лексичного матеріалу тощо [7].

У 70-х - 80-х pp. ХХ ст. з метою отримання більш міцних професійних знань пропонувалося використовувати на заняттях з іноземної мови в немовних вишах країнознавчі коментарі (В. Скрознікова, Р. Боданкіна й ін.). Автори розглядали країнознавчий матеріал як одну 3 основних форм реалізації міждисциплінарних зв'язків. Вони наголошували на тому, що короткі коментарі країнознавчого або лингвокраїнознавчого характеру чітко виявляють зв'язок практики навчання іноземних мов зі змістом програм інших навчальних дисциплін, позитивно впливаючи на формування у студентів немовних вишів більш глибоких професійних знань. На думку дослідників, “назріла необхідність у створенні професійно орієнтованих посібників, які б містили країнознавчий матеріал” $[15,115]$. 


\section{ТЕНДЕНЦІї ЙОСОБЛИВОСТІ ВИВЧЕННЯІНОЗЕМНИХ МОВ МАЙБУТНІМИ ВЧИТЕЛЯМИ НЕФІЛОЛОГІЧНИХ СПЕЦІАЛЬНОСТЕЙ У 70-Х - 80-Х РОКАХ ХХ СТОЛІТТЯ}

У цей період підвищується інтерес майбутніх учителів до дисципліни “Іноземна мова", зокрема до проблеми самостійної роботи з розширення своїх професійних знань засобами іноземної мови. Такий інтерес пояснювався тим, що в умовах зростання обсягу професійних знань, необхідних майбутнім фахівцям, важливим було навчити їх орієнтуватися в потоці інформації з обраною педагогічної спеціальності. У зв'язку з цим велика увага приділялася підбору високоінформативних професійних текстів і розробці різнорівневих тренувальних вправ.

Доволі поширеним методом серед викладачів англійської мови стало використання в освітньому процесі системи тренувальних вправ, особливо їх найуживанішого виду - підстановчих. Популяризацією цієї навчальної технології займався відомий вітчизняний учений О. Вишневський, який на основі власного дослідження у 1979 р. опублікував посібник “Підстановчі вправи з англійської мови” [2]. Щодо ефективного використання форм і методів організації навчання англійської мови як школярів, так і студентів немовних вишів, то багатьом педагогічним і науково-педагогічним працівникам у нагоді стала фундаментальна методична праця О. Вишневського “Діяльність учнів на уроках іноземної мови” [1].

Таким чином, наприкінці 80-х рр. ХХ ст. ученими-педагогами були висловлені актуальні пропозиції щодо відбору та структурування змісту навчального матеріалу, впровадження нових принципів і методів викладання іноземних мов, вдосконалення форм і засобів організації освітнього процесу, проте в силу низки причин негативного характеру (нестача науковопедагогічних кадрів відповідної кваліфікації; жорстка уніфікація навчальних програм; зменшення кількості годин на вивчення іноземної мови до 120; надмірне перевантаження студентів через інтенсифікацію освітнього процесу; низький рівень підготовленості абітурієнтів та ін.) чимало новацій не було втілено в практику іншомовної підготовки майбутніх учителів нефілологічних спеціальностей.

Розвиток методики в цей період характеризується активізацією досліджень 3 теорії і практики навчання іноземних мов. Однак різнобічні та багатопланові дослідження в галузі методики викладання іноземних мов, як у середній, так і у вищій школах потребували певної систематизації.

Дійсно, в умовах обмеженої кількості годин, що відводилися на вивчення іноземної мови у немовних вишах, методисти були змушені шукати шляхи оптимізації освітнього процесу, підвищення ефективності викладання. Розв'язання цих проблем відбувалося за декількома напрямами, котрі можна визначити як: організація самостійної

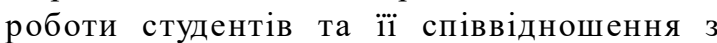
аудиторного роботою; специфіка підсумкового і рубіжного контролів всіх видів мовленнєвої діяльності; розробка нових типів підручників 3 іноземної мови для немовного вишу; оптимізація використання технічних засобів навчання в аудиторній та самостійній роботі студентів тощо.

Методисти виокремили та систематизували основні принципи навчання іноземної мови в немовному виші: принцип практичної (комунікативної) спрямованості; принцип диференційованого підходу до навчання; принцип усної основи та усного випередження; принцип паралельного навчання всіх видів мовленнєвої діяльності; принципи структурно-функціонального та функціонально-структурного підходу, які передбачали обгрунтований відбір мовного i мовленнєвого матеріалу та подання його в структурах, мовних одиницях і зразках мовленнєвих висловлювань; принцип навчання на мовленнєвих зразках; принцип опори на негативний досвід використання іноземної мови та ін. Однак слід наголосити, що вчені-педагоги так і не спромоглися виробити єдиного підходу до класифікації й ієрархічного розташування (використання) системи дидактичних принципів, оскільки відмовилися від визнання єдиного універсального методу навчання іноземних мов. Тому до кінця 80-х рр. превалювали граматикоперекладний, текстуально-перекладний та свідомо-порівняльний методи навчання іноземної мови майбутніх учителів нефілологічних спеціальностей, в основі яких було використання граматичних вправ і переклад текстів з фаху. Ці методи зумовлювали появу в студентів “мовного бар'єру”, не сприяли формуванню їхньої комунікативної компетенції.

У період 70 - 80-х рр. ХХ ст. на вивчення іноземних мов майбутніми учителями нефілологічних спеціальностей впливали передовсім соціально-політичні чинники, тобто система поглядів, ідей, переконань, цінностей та установок, що виражала ідеологічні інтереси панівної КПРС, і засвоєння яких організовувалося в умовах сприйняття світу як двох ворогуючих таборів - соціалістичного і капіталістичного. Лише наприкінці радянського періоду спостерігається підвищення ролі культурних, професійних, особистісних цінностей завдяки використанню лінгвокраїнознавчого підходу.

Висновки. Підводячи підсумок, відзначимо 


\section{ТЕНДЕНЩЇЙОСОБЛИВОСТІ ВИВЧЕННЯІНОЗЕМНИХ МОВМАЙБУТНІМИ ВЧИТЕЛЯМИ НЕФІЛОЛОГІЧНИХ СПЕЦІАЛЬНОСТЕЙ У 70-Х-80-Х РОКАХ ХХ СТОЛІТТЯ}

основні тенденції й особливості вивчення іноземних мов майбутніми вчителями нефілологічних спеціальностей в останні десятиліття радянського періоду:

1) поступове зростання потреб суспільства у вивченні іноземних мов; збільшення зарубіжних контактів радянських людей (особливо у часи “перебудови”, з середини 80-х рр. ХХ ст.);

2) підвищення рівня методики навчання іноземних мов як галузі педагогічної науки;

3) розширення міждисциплінарних зв'язків i збільшення кількості соціокультурних реалій на сторінках навчальної літератури, котрі стосуються англомовних країн;

4) збільшення кількості термінів і понять, які складають категоріально-понятійне поле міжкультурної та комунікативної компетенцій;

5) поступова відмова від визнання єдиного універсального методу навчання іноземної мови й актуалізація питання щодо необхідності формування у студентів лінгвокраїнознавчих знань й умінь;

6) незмінність основної мети вивчення іноземної мови майбутніми вчителями нефілологічних спеціальностей - підготовка до читання і перекладу іноземної літератури з фаху.

Подальших досліджень потребує вивчення порушеної у статті проблеми в контексті вдосконалення процесу професійно орієнтованого навчання іноземних майбутніх учителів нефілологічних спеціальностей на сучасному етапі розвитку педагогічної освіти.

\section{ЛІТЕРАТУРА}

1. Вишневський О. І. Діяльність учнів на уроках іноземної мови: посібник для вчителів. Київ, 1989. 223 с.

2. Вишневський О. І. Підстановчі вправи 3 англійської мови: посібник для вчителів. Київ, 1979. 144 c.

3. Гальскова Н. Д., Горчев А. Ю., Никитенко 3. Н., Соловцева Э. И. Обучение иностранным языкам: поиск новых путей. Иностранные языки в шкколе. 1989. № 1. С. 13-16.

4. Доповідні записки Міністерства освіти УРСР до Ради Міністрів УРСР 3 питань загальної середньої освіти. ЦДАВО України (Центр. держ. архів вищ. органів влади та упр. України). Ф. 166. Оп. 10. Спр. 728. Т. III. 572 арк.

5. Зведені статистичні звіти педагогічних інститугів Міністерства освіти УРСР за 1972-1973 навчальний рік: Форма № 4-НК. ЦДАВО України (Центр. держ. архів вищ. органів влади та упр. України). Ф. 166. Оп. 15. Арк. 1.

6. Зведені статистичні звіти вищих навчальних закладів Міністерства освіти УРСР за 1986-1987 навчальний рік. ЦДАВО України (Центр. держ. архів вищ. органів влади та упр. України). Ф. 166. Оп. 18. Д. 10, Арк. 78.

7. Ляховицкий М.В. Методика преподавания иностранных языков. Москва, 1981. 160 с.

8. Ляховицкий М. В. О некоторых базисных категориях методики обучения иностранным языкам. Иностранные языки в школе. 1973. № 1. C. 27-34.

9. О пересмотре и дальнейшем совершенствовании учебных планов высших учебных заведений: инструктивное письмо Министерства высшего и среднего специального образования СССР № 29 от 2 октября 1981 г. Бюллетень Министерства высшего и среднего специального образования СССР. 1981. № 12. С. 6-7.

10. Об улучшении изучения иностранных языков: Постановление Совета Министров СССР от 27 мая 1961 г. № 468. Дата оновлення: 14.01.2019. URL : http://www.libussr.ru/doc_ussr/ usr $5690 . \mathrm{htm}$

11. Осіпчук Н. В. Розвиток мовної підготовки студентів вищих технічних навчальних закладів у радянський час. Оновлення змісту, форм та методів навчання і виховання в закладах освіти: наукові записки Рівненського державного гуманітарного університету. Рівне, 2014. Вип. 9 (52). С. 122-125.

12. Основные направления перестройки высшего и среднего специального образования в стране: Постановление ЦК КПСС и Совета Министров СССР. Правда. 1987. 21 марта.

13. Політична історія України XX століття : у 6 т. / Майборода О. М. та ін. Київ: Генеза, 2003. Т. 6: Від тоталітаризму до демократії (1945 2002 pp.). 696 c.

14. Рощина Е. В. Функции иностранного языка как учебного предмета в системе обучения в университете. Иностранные языки на неспецииальных факультетах: межвуз. сб. Ленинград, 1978. С. 3-6.

15. Скрозникова В. А., Боданкина Р. Н. Страноведческий комментарий как одна из форм реализации межпредметных связей. Иностранные языки в высшей школе. 1978. Вып. 13. С.113-116.

\section{REFERENCES}

1. Vyshnevskyj, O. I. (1989). Diialnist uchniv na urokakh inozemnoi movy: posibnyk dlia vchyteliv [The activities of students at foreign language lessons: a manual for teachers]. Kyiv, 223p. [in Ukrainian].

2. Vyshnevskyj, O. I. (1979). Pidstanovchi vpravy z anhlijs'koi movy: posibnyk dlia vchyteliv [Wildcarding 
English Exercises: a manual for teachers]. Kyiv, 144 p. [in Ukrainian].

3. Gal'skova, N. D., Gorchev, A. Yu., Nikitenko, Z. N. \& Solovtseva, E. I. (1989). Obuchenie inostrannym yazykam: poisk novykh putey [Teaching foreign languages: finding new ways]. Foreign languages at school, no. 1,pp. 13-16. [in Russian].

4. Dopovidni zapysky Ministerstva osvity URSR do Rady Ministriv URSR z pytan zahalnoi serednoi osvity [Reports of the Ministry of Education of the USSR to the Council of Ministers of the Ukrainian SSR on general secondary education]. Central State Archive of the Supreme Power and Administration of Ukraine, F. 166. Op. 10. Case. 728. Vol. III. 572 p. [in Ukrainian].

5. Zvedeni statystychni zvity pedahohichnykh instytutiv Ministerstva osvity URSR za 1972-1973 navchalnyj rik [Summary statistical reports of pedagogical institutes of the Ministry of Education of the Ukrainian SSR for the 1972-1973 academic year]. Central State Archive of the Supreme Power and Administration of Ukraine, F. 166. Op. 15. p. 1. [in Ukrainian].

6. Zvedeni statystychni zvity vyschykh navchalnykh zakladiv Ministerstva osvity URSR za 1986 - 1987 navchalnyj rik [Summary statistical reports of higher educational institutions of the Ministry of Education of the Ukrainian SSR for the 1986 - 1987 academic year]. Central State Archive of the Supreme Power and Administration of Ukraine, F. 166. Op. 18. D. 10, p. 78. [in Ukrainian].

7. Lyakhovitskiy, M.V. (1981). Metodika prepodavaniya inostrannykh yazykov [Methods of teaching foreign languages]. Moscow, 160p. [in Russian].

8. Lyakhovitskiy, M. V. (1973). O nekotorykh bazisnykh kategoriyakh metodiki obucheniya inostrannym yazykam [On some basic categories of methods of teaching foreign languages]. Foreign languages at school, no.1, pp. 27-34. [in Russian].

9. O peresmotre i dalneyshem sovershenstvovanii uchebnykh planov vysshikh uchebnykh zavedeniy: instruktivnoe pismo Ministerstva vysshego i srednego spetsialnogo obrazovaniya SSSR no. 29 ot 2 oktyabrya 1981 g.[On revision and further improvement of curricula of higher educational institutions of the USSR No. 29 of October 2, 1981]. Bulletin of the Ministry of Higher and Secondary Special Education of the USSR, no. 12, pp. 6-7. [in Russian].

10 . Ob uluchshenyy yzuchenyya ynostrannych yazykov [On improving the study of foreign languages]. Resolution of the Council of Ministers of the USSR of May 27, 1961 No. 468. Date of approval: 01/14/2019. Available at: http://www.libussr.ru/ doc_ussr/usr_5690.htm[in Russian].

11. Osipchuk, N. V. (2014). Rozvytok movnoi pidhotovky studentiv vyschykh tekhnichnykh navchalnykh zakladiv u radianskyj chas [Development of language level of students of higher technical educational institutions in Soviet times]. Updating the content, forms and methods of teaching and education in educational institutions: scientific notes of the Rivne State Humanitarian University. Rivne, no.9 (52), pp.122-125. [in Ukrainian].

12. Osnovnye napravleniya perestroyki vysshego i srednego spetsialnogo obrazovaniya v strane (1987). [The main directions of the restructuring of higher and specialized secondary education in the country]. Resolution of the Central Committee of the CPSU and the Council of Ministers of the USSR [in Russian].

13. Majboroda, O. M. et al. (2003). Politychna istoriia Ukrainy XX stolittia [The political history of Ukraine of the twentieth century]. From totalitarianism to democracy (Vols. 1-6; Vol. 6). Kyiv, 696 p. [in Ukrainian].

14. Roshchina, E. V. (1978). Funktsii inostrannogo yazyka kak uchebnogo predmeta $\mathrm{V}$ sisteme obucheniya $\mathrm{v}$ universitete [Functions of a foreign language as a subject in the system of university education]. Foreign languages at non-specialized faculties. Leningrad, pp. 3-6. [in Russian].

15. Skroznikova, V. A. \& Bodankina, R. N. (1978). Stranovedcheskiy kommentariy kak odna iz form realizatsii mezhpredmetnykh svyazey [Cultural commentary as a form of interdisciplinary communication]. Foreign languages in higher education institutions, no. 13, pp.13-116. [in Russian].

Стаття надійшла до редакції 22.05.2019

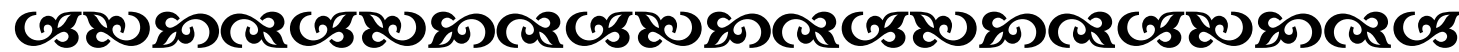

"Стає майстром педагогічної праиі швидше всього той, хто відчув у собі дослідника".

Василь Сухомлинський украйнський педагог, публіиист, письменник

\section{G58080ल2058080}

